\title{
THE POTENTIAL AND SURVEILLANCE STUDIES ALUMNUS FACULTY OF ECO- NOMICS AND BUSINESS ISLAM UIN RADEN INTAN LAMPUNG
}

\author{
Hanif \\ UIN Raden Intan Lampung \\ hanif@radenintan.ac.id
}

Diterima: 21 Desember 2019; Direvisi: 10 Januari 2019; Disetujui: 15 Januari 2019

\begin{abstract}
Alumni searches (Tracer study) as part of an alumni network construction should be done regularly and scheduled. The alumni FEBI can generally be absorbed in the world of work with a waiting period of normal working ranges of less than 3 (three) months and the majority of alumni working in the field of employment in accordance with their competence. Based on the results of the questionnaire tracer study, the majority of graduates in response to their competence as a result of the learning process in Febi, pretty good. Alumni also commented that soft skill competencies they have higher than hard skills and competencies it has in accordance with the needs of the working world are increasingly demanding mastery of soft skills.
\end{abstract}

Keywords: $\quad$ Potential, Tracer Study, FEBI

\begin{abstract}
Abstrak
Pencarian alumni (Tracer study) sebagai bagian dari pembangunan jaringan alumni harus dilakukan secara teratur dan terjadwal. Alumni FEBI umumnya dapat terserap di dunia kerja dengan masa tunggu rentang kerja normal kurang dari 3 (tiga) bulan dan mayoritas alumni yang bekerja di bidang ketenagakerjaan sesuai dengan kompetensinya. Berdasarkan hasil studi penelusuran kuisioner, mayoritas lulusan dalam menanggapi kompetensinya sebagai hasil dari proses pembelajaran di Febi, cukup baik. Alumni juga berkomentar bahwa kompetensi soft skill yang mereka miliki lebih tinggi dari hard skill dan kompetensi yang dimilikinya sesuai dengan kebutuhan dunia kerja yang semakin menuntut penguasaan soft skill.
\end{abstract}

Kata Kunci: Potensi, Tracer Study, FEBI 


\section{BACKGROUND}

Education is a business carried on by a person or group of others to become mature in terms of biological, psychological, paedagogis, in accordance with the

values of society and culture (Hasbullah, 1999). Education is basically a cultural transition (transition of culture) that is dynamic towards a change in a continuously (continuous), then education is considered as a vital bridge to develop the culture and civilization of man. As a process of cultural transformation, education is defined as the activities of the cultural inheritance from one generation to another (Umar Tirtarahardja, 2005). Education constitute the main tool for the development and determine the future of the nation/the community (Muri Joseph, 2006).

Education, especially higher education, today is expected to be able to produce graduates who have the competency skills (practical and theoretical) in accordance with the needs of the workforce, in line with the Presidential Decree No. 8 of 2012 on the National Curriculum-based KKNI (Indonesian National Qualifications Framework), KKNI is a frame work level Indonesia qualification of human resources, which is put, equalizes, and integrating education sector by sector training and work experience in a recognition scheme workability adapted to the structure in many employment sectors (Presidential Decree No. 8 of 2012).
Indonesian National Qualifications Framework (KKNI) is the frame of reference of at least the size, the recognition of the educational hierarchy do. KKNI also referred to as a competence and qualifications framework hierarchy to reconcile, equalize, and integrate the fields of education and job training and work experience in order to award the work in accordance with the recognition of the competence of the structure of employment in various sectors.

In KKNI perspective, every program of study is required to clarify the "Graduate Profile" expected through activity tracking studies, feasibility studies and analysis of the needs in the community. Profile of graduates reflects the minimal ability to master students after graduating which refer to the four aspects of the needs, the attitude (attitude) field work ability knowledge and managerial responsibilities. Fourth ability must then be translated into a learning outcomes (learning outcomes) on each of the subjects in the study program. So later, all the planning for learning or Semester Implementation Plan (RPS) should be based on learning outcomes (Learning Outcome) that fits the needs of the graduate profile.

In connection with this context there are two key words to link the curriculum with Indonesian National Qualifications Framework, namely the achievement of learning (learning outcomes) and qualifications (Directorate General of Higher Education, 2013). This 
means that the learning outcomes packaging into KKNI qualification levels is essential for pairing and equalization purposes or recognition of qualifications and the level of education or employment levels. His relationship with KKNI, that at every stage or level contains three outcomes are integrated with each other, namely skills (cognitive and psychomotor) owned by a student after completing a course of lectures; knowledge (content knowledge) that underlies the skills possessed to be able to adapt to change in the foreseeable future, managerial capabilities for the skills and knowledge mastered in order to develop in accordance with the demands of his professional (Ali Akbar Jono, 2016), especially in the working world.

The existence of a Higher Education is strongly associated with the extent of utilization of graduates in the working world. The world of work as stakeholders, we must increase the level of kepercayaanya, to maintain stakeholder confidence level there are at least three key factors that must be considered are: appearance, services and products. Appearance institution can be seen from the availability and completeness of facilities and infrastructure that is comfortable and safe and responsible use in supporting the implementation of the Tri Dharma College. Service to the community is shown by the existence of a set of procedures and policies and performance indicators are clear and complete for the sake of ensuring the excellent service, while the product, in this case generated alumni,
In order to carry out the task of quality management of higher education the Faculty of Economics and Business Islam UIN Raden Intan Lampung need to plan for quality based on the needs of stakeholders, in particular students and the graduates, then one will have to do is to identify and analyze the data needs of students, alumni and the world of work, Alumni revenue potential is the ability of an institution or agency to accommodate graduates to be employed in accordance with the discipline, both based on the level of qualification or level of education. Cambell and Panzano, as quoted by Samani Muchlas, said that six important aspect determining the success of the alumni were accepted in the world of work are competent, able to interact in a positive, confident in doing the task,

Alumni Tracking is part of the identification process to see the achievements of graduates in terms of aspects relevance of basic competencies desired by a user graduates graduates. Besides tracking of alumni is an attempt to get information. Tracking the alumni are part of the stage to the planning and decision-making, especially related to the implementation of the process of learning, curriculum relevance and competence of graduates with the needs of the workforce.

Alumni searches (Tracer study) is the study of trace tracking graduates /alumni who performed two years after graduation and study aims to determine the outcome in the form of transition from higher education to the world 
of work, the last working situation, alignment and application competence in the workplace. Tracer studies can also provide educational information regarding the output Febi namely self-assessment of the acquisition and the acquisition of competencies, the educational process include evaluation of the learning process and the contribution of higher education to the acquisition of competencies and Educational input be further excavations to information sosio biografis graduates.

Tracking studies graduates or graduates was empirical research can yield valuable information in evaluating an educational program. Information such studies can be used as a quality assurance for the institution as a whole, in the sense that institutions conduct continuous improvement program corresponding to the input of the search results of studies graduates (Schomburg, 2003). Tracking studies graduates Alumni play a role in evaluating the curriculum a course of study, demonstrate the advantages and weaknesses of the program so as to produce a fundamental improvement suggestions. Febi graduates generally have stronger ties to the institution of learning, then alumni perceptions and perspectives are more objective in evaluating the learning program that has been taken.

According to Zembere dan Chinyama in the Tri Suryati dkk. (2012), explained that main object study the search for alumni is research the transition process of education higher to the world of work, analysis the relationship between higher education with the world of work from the perspective of the purpose of individual as satisfaction work and position of employment, income, security work, and types of occupation.

\section{METODE}

The search is a descriptive study was conducted on an ongoing basis against college graduates, about the various datayang concerned graduates, such as the cumulative Achievement Index (IPK), duration of study, type of work, long time get a job and a salary beginning. Search studies is a method of execution tracer study against alumni. Through the tracer study College can obtain the required information and data. Search studies is a way to obtain needed information from College alumni are known as the tracer study.Tracer study search alumni is to know the activities of alumni after graduating from college, the transition from the world of higher education to the world of work, the employment situation, the acquisition of competencies and the use of competency in job and career. According to Soemantri dkk (2010), graduates (tracer study) is one of the things that should be done by each educational institution.

\section{RESULT AND DISCUSSION}

Tracer study activities can also be used to find information about the needs of companies or institutions against alumni of the College. The purpose of this activity is to gather relevant information and input from graduates about 
AGREGAT: Jurnal Ekonomi dan Bisnis

Vol. 3, No. 1, Maret 2019

http://journal.uhamka.ac.id/index.php/agregat

p-ISSN: 2549-5658 e-ISSN: 2549-7243

DOI: 10.22236/agregat_vol3/is1pp81-96

Hal 85

learning and work experience experienced by graduates of the College for development. According to Harald Schomburg in Soemantri dkk. (2010), extended "Tracer study is an approach that enables higher education institutions get information about flaws that may occur in the process of education and the learning process and can be a the basis for planning activity for consummation in the future ".

According to Wuradji et al. (2010) that a search of graduates (tracer study) is an important part of the activities of an educational institution. Search graduates will be obtained through a variety of important information is very beneficial to the institution, for graduates, and also other institutions related to the Organization of education. Tracer study allows an institution to track the condition of graduates and from information obtained can be taken a wide range of policies and actions that provide benefits to graduates and to the development of institutions that concerned. According to Nazir in Nuroso Soeharto dkk. (2008), "tracer study (study of search) is the main focus of the study is to obtain the existence of or information from graduates who are already working or not working".

The activities of the tracer study can provide information obtained from graduates who managed to diprofesinya, such as knowledge, skills, and job demands, work area, and the position of the profession who do graduate. Graduates can provide information on education and learning process during their lectures

in college. This is as described by Syafila in Lieli Suharti and Ferrynela (2012) which explains that the tracer study is an approach that allows institutions of higher learning to obtain information about the various shortcomings that may occur in the process of education and the learning process and can be the basis for planning activities for future refinement. According to Mario Anthony B, tracer study is a study tracking the footsteps of graduates or the alumni committed to alumni of the two (2) years after graduation (first survey) and five (5) years after graduation (second survey). Meanwhile, according to the Ministry of education and culture, is the tracer study study tracking the footsteps of graduates or the alumni conducted between one (1) year three (3) years after graduation. According to the National Accreditation Body-higher education (BAN-PT) as cited by Ainil Fitri (2010) in its research report that there were some elements of the assessment that is used to look at the effectiveness of the standards of the graduates are. Services and utilization of graduates, including variety, type, container, quality, price, and intensity. Tracking and recording data on graduates, including komprehensive, the profile of the first job waiting period, the suitability of the field work with majors, and position the work first. Participation of the graduates and alumni in supporting the development of academic and non-academic Courses.

Based on some explanation as reflected above, then it can be inferred that the alumni search studies is one way to get the informa- 
tion and data required such high profile College graduates, long waiting period in get a job, type of work, work placements, and income or salary earned in each month of college alumni. Search the graduate tracer study is generally called the activity at an educational institution whose primary focus is to obtain information or where abouts of graduates who had worked or not worked, later the information can the and action policy is used to provide benefits for graduates and for developers the institution.

As for the objective, the Schomburg in Soemantri dkk. (2010), the main goal of from the activities explains that the tracer study is to know or identify the quality of graduates in the workforce, while special-purpose tracer study is, identifying the competency profile and skills of graduates, relevance of the implementation of the curriculum that has been applied in college with the needs of the labour market and the development of professional competence within the department, to evaluate the relationship of curriculum and study in the department as a scientific development and as a contribution in the process of accreditation Department.

The activities of the Tracer Study is beneficial to enhancing the relationship of graduates and Alma Mater, as can be seen from the experience of renowned educational institutions, bonds alma mater strong and graduates can bring many benefits to the alma mater as with use of gait graduates in the community. Tracer
Study is an approach that allows institutions of higher learning information about the shortcomings of the may occur in the process of education and the learning process. The result of the tracer study of the College can be used to find out the success of the educational process which has been done to the children of his protégé.

As for the waiting period work alumi according to the portfolio Valuation Guidelines Book V Institutional Accreditation of the College of the year 2007, the elements of the standard assessment graduates was "waiting period graduates to work relatively brief, colleges have efforts tracking graduates to do periodically, College provides career guidance and employment information for students and graduates". Based on BAN-PT (2008) in Ainil Fitri (2010), length of waiting period work graduates to earn his first job after graduation requires a short time i.e. less than 3 months. According to another opinion, the employment waiting period is the period or time span of passing grade alumni to get work.

Inauguration initial establishment of the Faculty of Economics and Business Islam (Febi) UIN Raden Intan Lampung is dated August 11, 2015, which at that time still a UIN Raden Intan as IAIN Raden Intan Lampung. At the beginning of the formation, Febi Prodi only has two and one concentration, namely the Economic Prodi Prodi Shariah and Shariah Banking and Accounting concentration Sharia. Febi before an existing study programs in $\mathrm{Ra}-$ 
den Intan Faculty of Shariah UIN Lampung, which is one of the five faculties at UIN Raden Intan Bandar Lampung today.

The existence of this Faculty has a very long history since it was founded in 1968, the history of the Faculty of Shariah UIN Raden Intan Lampung is inseparable from the history of the UIN Raden Intan Lampung, namely through consultation Ulama Lampung in Lampung Tengah Metro as the capital of the time, in order to establish the Islamic Welfare Foundation Lampung (YKIL) in 1963, which gave birth to the establishment of the College of Islamic Religion (PTAI). So that in that year (1963) the establishment PTAI to open two (2) of the Faculty, the Faculty of MT and Faculty of Shariadi Lampung under the patronage of and compensation for YKIL with the location of offices and classrooms were placed in the Hall of the Faculty of law of the road Fob Hasanuddin No. 1 Telukbetung. After a few months of the second lecture of the Faculty shifted to the Masjid Jami ' Lungsir Teluk betung, now called masjid Jami ' Al-Furqon.

Faculty of Shari'ah UIN Raden Intan Lampung dinegerikan in conjunction with the inauguration of IAIN Raden Intan Tanjungkarang with Letter Decision 68 (SK) Minister of religious affairs RI Number 187 Year 1968 on 26 October 1968 in conjunction with Hasan Mukhtar, s. H was appointed Rector IAIN al-Jami'ah al-Islamiyya al-Hukumiyyah Raden Intan and $\mathrm{m}$. Zubair Djuaini $\mathrm{SH}$ as Secretary. Lectures and activities at the time were held in the building of the Chinese school in the way Ex Kartini Kaliawi Cape Coral. (IAIN, 2001).

At the time of dinegerikan, Faculty of Shari'ah UIN Raden Intan Lampung based SK Minister of religious affairs RI No. 187 year 1968 had two departments, namely the Department of religious courts (PA) Criminal Islamic Civil and courses (PPI), which has the task of carrying out the activities education and instruction, the penelitiandan community in the field of Law and Sharia (Islamic law and positive law). (IAIN, 2001).

At the moment, FEBI UIN Raden Intan which originated from the opening of the Economic Studies Program at the Faculty of Shari'a Shari'ah in 2006 and obtained the permission of operations, then in the year 2013 following the Sharia Banking Course opened. See the community growing in great numbers from year to year and in 2015 year officially FEBI stands alone and apart from the Faculty of Shari'ah.

Currently Febi has had 4 Department / Economics Prodi Prodi namely Shariah and Shariah Banking Prodi has had accreditation, Prodi Accounting and Business Management Shariah Shariah is still at the stage of operational licenses. Although still relatively young to support quality learning, Febi has had with the local College Building class numbered 36 rooms divided into 3 units of 2-storey building and one 3-storey building as a center Dean faculty administration. Febi means of lectures 
supported by various facilities such as LCD projectors, whiteboards, laptops and other means. The number of such facilities has been bias used for all of the lecture hall. Means of supporting the education that is Lab. Bank Mini and Lab. Computers are used for practical activities, while the supporting infrastructure in the field of information technology is the presence of several point hot-spot for wireless Internet in Febi environment. Each student is entitled to have access to internet with high speed provided by the college.

Of the 35 respondents were sampled in this study, to distinguish the sex of the respondent. The composition of the respondents in terms of the sex of the respondents who participated in the study $28.5 \%$ were male and $71.4 \%$ were female.

Furthermore, respondents by age. These respondents age grouping aims to determine the age group participating in the tracer study questionnaire in this study. All respondents in this study aged $20-25$ years $(100 \%)$.
In the aspect of the learning experience, pengalaman study is expected to bring a positive influence within the competence of students in the form of implementation, performance improvement, and the willingness of lifelong learning. To mengeahui graduate learning experience while studying in Febi, aspects studied in tracer studies are: aspects of learning and teaching, facilities and learning conditions and the impact of learning experiences and the benefits of learning in Febi.

In the aspect of learning, tracer studies It aims to find out the extent to which aspects of learning can provide a positive contribution which can add to the learning experience. In more detail it is measured from the practical knowledge, theories and empirical concept, independent study, tutorial learning materials Print learning as a primary source, a non print materials, as the main source of information. End of the program assignment and exam courses regularly. For more details can be seen in the image below:

\section{Figure 1}

Aspects of Learning

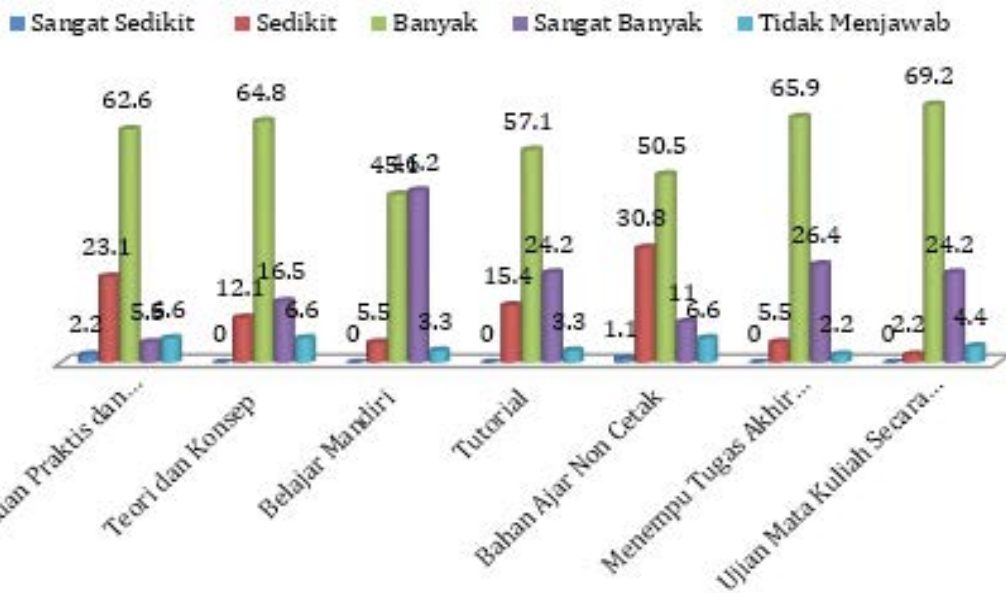


AGREGAT: Jurnal Ekonomi dan Bisnis

Vol. 3, No. 1, Maret 2019

http://journal.uhamka.ac.id/index.php/agregat

p-ISSN: 2549-5658 e-ISSN: 2549-7243

DOI: 10.22236/agregat_vol3/is1pp81-96

Hal 89

On Figure 3 above, this research can identify that aspect of independent study revealed the majority of respondents $(91.3 \%)$ provide a great learning experience. These findings indicate that the system is open and independent learning are applied Febi UIN Raden Intan Lampung in the learning process has been very helpful that can be applied in the workplace by Raden Intan UIN Febi graduate Lampung. In addition to independence, the test subjects on a regular basis and take the final as well as tutorials printed teaching materials as a major source of learning is learning which aspects are very much helpful perceived (reaching a percentage above 90\%). Followed by the understanding of the theories and concepts (over $80 \%$ said a lot and very much benefit in its application).

Although it is common for all indicators in the application of learning assessed by the graduate application can already be implemented, but there are some of the respondents $(31.9 \%)$ stating that non-print materials as a

primary source of information is still considered lacking in the application followed the aspect of practical knowledge and empirical $(25.2 \%)$. Thus it can be stated that the aspects of learning that students were optimal implementation rated useful in the work is independent study, test subjects on a regular basis and take the exam in the final project.

In the aspect of facilities and learning conditions, tracer studyIt aims to map the extent of the facilities and learning conditions of students accepted for study at UIN Febi Raden Intan Lampung. The facilities and learning conditions that can be given FEBI UIN Lampungsecara Raden Intan well to the students will help to expedite the learning process that will have an impact on the quality of learning. In more detail it is measured from several aspects: academic tutoring, course materials, diversity of programs of study offered, the assessment system, a collection of library books, teaching materials availability and quality of services provided Febi (figure 2).

Figure 2

Conditions and Learning Facilities

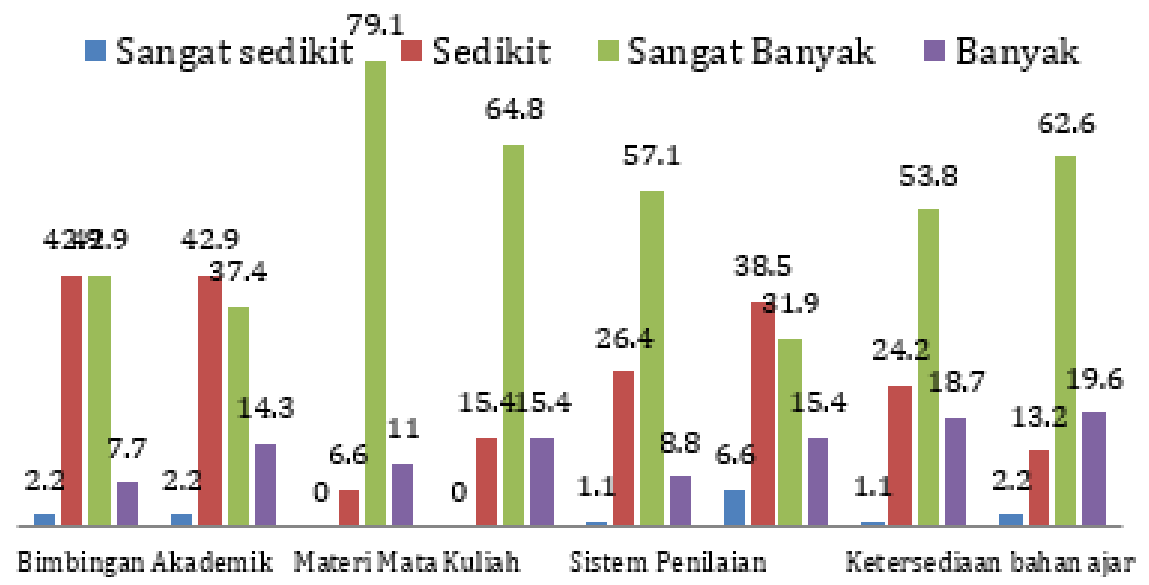


The results showed that most respondents $(90 \%)$ stated that the course material has been very much a positive learning experience, followed by the quality of the service provided Febi (82.4), the diversity of courses offered and the availability of teaching materials $(72.6 \%)$ and the assessment systems (65.9\%). Positive assessment of graduates Febi UIN Raden Intan Lampung indicates that the following lecture material availability and ratings system had been given a very great experience in the learning process.

However, some aspects of the facilities and learning conditions that they feel while studying in Febi UIN Raden Intan Lampung rated graduates have not given Febi optimally include guidance for final exams and academic advising in general, where the majority of respondents (45\%) express little experience felt. This means that there is a need for guidance, especially students during final exams can not be given byFebi the library book collection good. Moreover rated most graduates $(45 \%)$ is still lacking.

The research findings indicate that the facilities and learning conditions have not been optimally can help to achieve optimal learning with academic guidance and collection of library books. Low ratings for the possibility of aspects due to low accessibility of students to be able to borrow a good book in the library due to the limitations of the local library. With e-library facilities offered can solve this problem. Then from the side which is still considered low guidance role, likely due to a tutorial that followed the student can not provide a positive impact in overcoming the difficulties in academics and in the final exam.

On the impact of the learning experience, studi also explore the extent to which the impact of the learning experience can affect the knowledge, skills and knowledge sikap. Aspek impact on knowledge is the ability in the field of science diperoleh.Dari academic or skill aspect of the learning experience can improve the ability to communicate with superiors, peers, subordinate and in a formal forum. Judging from his attitude, then experience learn Febi expected to build independent and confident attitude (Figure 3 )

Figure 3

Impact Learning Experience

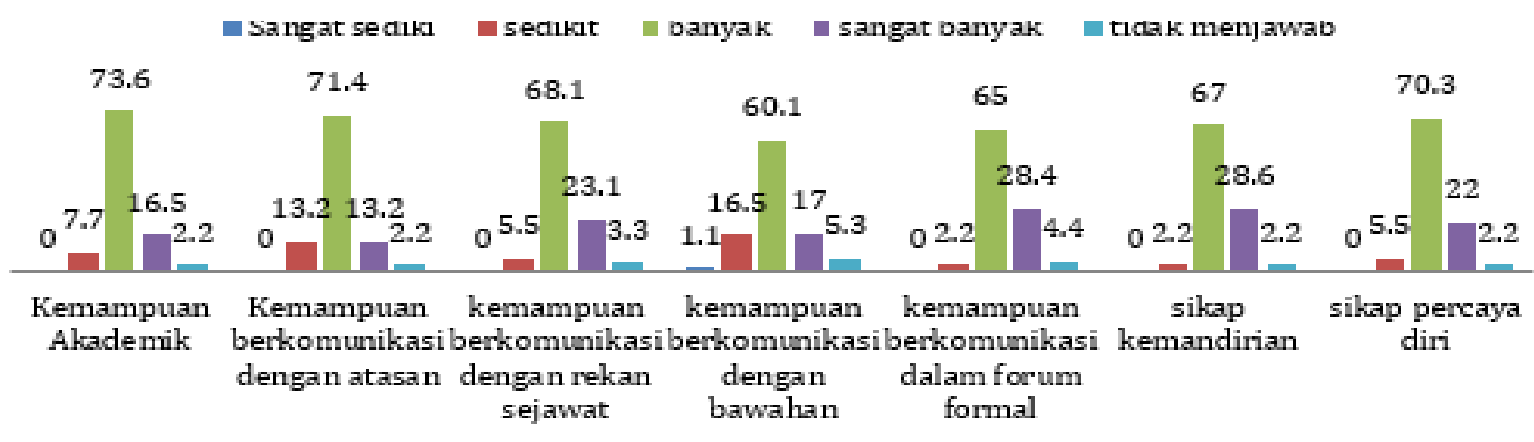


The results of the research presented in Figure 5 show generally that impact learning experiences in improving the knowledge, skills and attitudes rated graduates provide a great experience. From the aspect of knowledge of the majority of respondents $(90.1 \%)$ stated that the academic and scientific capability to show improvement. From the aspect of skill, learning experiences in Febi UIN Raden Intan Lampung improve communication skills, especially in a formal forum (85.5\%). That is a learning experience in Febi UIN Raden Intan Lampung rated graduates have a positive impact in improving the confidence to build networking through participation in a formal forum. The learning experience is perceived by graduates who have a positive impact on the knowledge and skills also in line with increasing aplomb $(92.3 \%)$ and the attitude of independence $(85.6 \%)$.

From the findings of this study indicate that aspects of the learning experience that is considered to provide a positive experience selamabelajar in Febi is a self-learning, and felt very much subject matter provides a positive learning experience, as well as the quality of service provided Febi, The impact of the learning experience for graduates is to increase academic skills, improve communication skills not only inwork environment on the forum formal. Next but independent attitude and confidence is increasing due to the impact of the learning experience for Febi.

In the aspect of further studies on the level S2 shown that, keinginan Islamic Economics graduate study program for proceedings in further studies (S2) after graduating from Prodi S1 Islamic Economics indicated a willingness to continue to learn menuntutilmu order to be useful, especially in the work environment. Berikutgambar below the data of graduates who went on and did not resume S2.

\section{Figure 4}

Data Respondents Continuing and Not Continue S2

\section{Lanjut S2 - TidakLanjut S2 Jumlah}

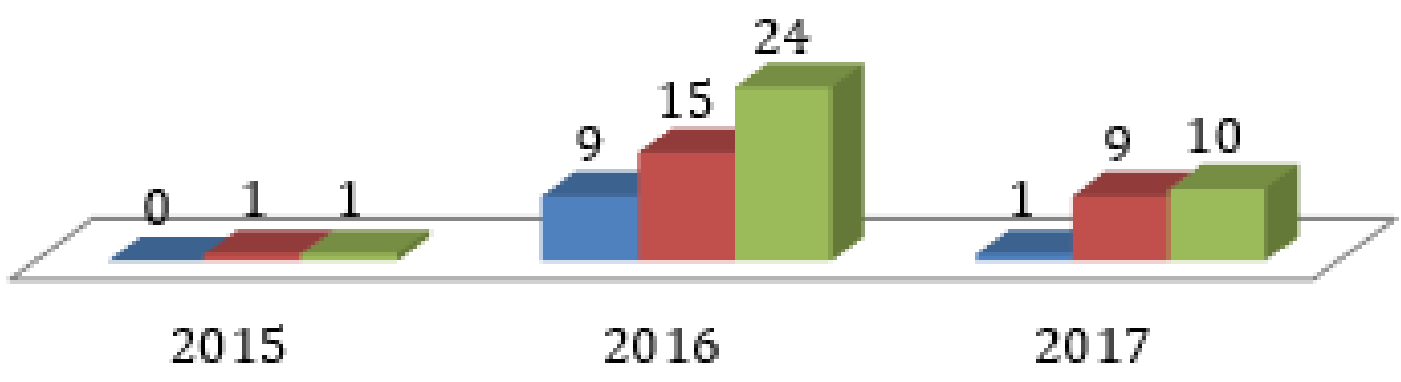


Based on the picture above shows that most graduates do not continue (71.4\%) to the level of S2, while states continue to pursue S2 (28.5\%). For 2015 graduates who did not continue their studies $\mathrm{S} 2$ as much as one person, while continuing there. For 2016 graduates who continue to pursue S2 were 9 people, while as many as 15 people had not progressed S2. For 2017 graduates who did not continue to pursue S2 as many as nine people, while continuing $\mathrm{S} 2$ level by 1 person. Low interest for further studies could be due to lack of significant changes S2 degree to career development.
In the aspect of job history after college levels seen that This study aimed to obtain information on how to get a job (Figure 7). The findings of this study show information from friends, relatives and acquaintances showed the first rank $(22.5 \%)$, followed by the Internet and newspaper ads (12.4\%), other information at $(11.2 \%)$ and their own initiative ( $9 \%)$ and the vacancy of the announcement on campus (7.9\%). These findings indicate that the conventional way in search of work remains dominant, of searching through the internet.

\section{Figure 5}

Employment Information Now

Informasi Pekerjaan Sekarang Persentase

\begin{tabular}{cr}
\hline in & Info Lowongan di Kampus \\
\hline+ & Inisiatif Sendiri \\
\hline$\infty$ & In formasi Lain \\
\hline$N$ & Iklan Internet dan Surat Kabar \\
\hline$\rightarrow$ & Teman Saudara dan Kenalan \\
\hline
\end{tabular}

Judging from the work information, the majority of respondents $(62.9 \%)$ stated that working in private followed in the administration $21,3 \%$. Another interesting finding in this study is there are some graduates $(7.9 \%)$ declare themselves as self-employed. Govern- ment programs forward toward encouraging graduates to become entrepreneurs so as to provide employment opportunities to others. So that graduates are not only looking for work but must create jobs through various business activities are performed. 
AGREGAT: Jurnal Ekonomi dan Bisnis

Vol. 3, No. 1, Maret 2019

http://journal.uhamka.ac.id/index.php/agregat

p-ISSN: 2549-5658 e-ISSN: 2549-7243

DOI: 10.22236/agregat_vol3/is1pp81-96

Hal 93

Figure 6

Agencies Working Place

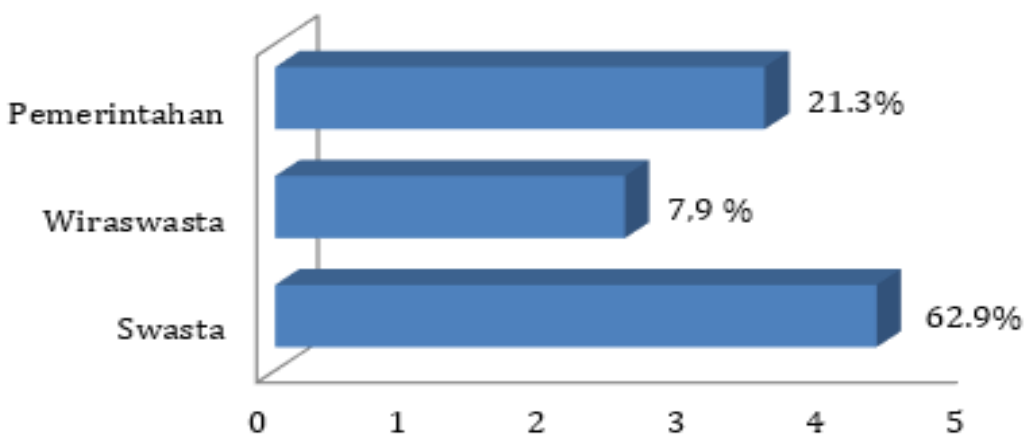

The above findings that showed most of the graduates work in the private institutions namely $62.9 \%$, followed by work on the part of government self-employed $21.3 \%$ and $7.9 \%$.

The success of the institution can be measured from a sanctioned individual competence. A successful education is reflected in the high berkompetensi graduates who fit the needs of the job. This study aims to identify the degree to which the education Prodi Sharia Economy can meet the needs of the world of work-related competences. Need to compare

student owned and competences competences required in the job.

Competence is focused on aspects of mastery or related field is in the Faculty of Economics and business, analytical thinking, the ability of performing under pressure, the ability to coordinate activities, manage time ability are efficient, the ability to work productively with others, the ability to use a computer or the internet, the ability to solve problems, the ability of the judge's own or other people's ideas and the ability to present ideas, results and reports.

Figure 7

The Competence of Graduates in Employment

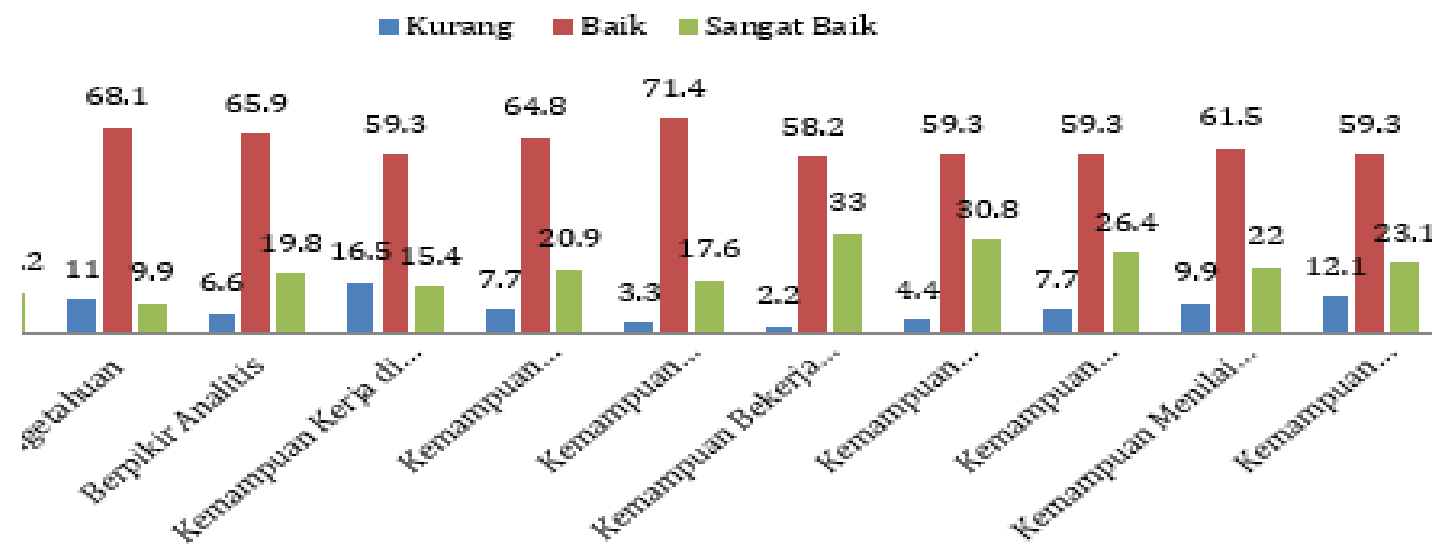


In the picture above shows the respon- $\quad(26.4 \%)$ and the ability to present ideas $(23.1 \%$ dents' current competence, generally can be ) as well as the ability to assess the idea (22\%). identified that the competence of graduates are Meanwhile, in terms of knowledge and masat a good level $(>59, \%)$, especially in terms tery of science graduates are not able to assess of scientific knowledge $(74.7 \%)$, the abilat a very $(9.9 \%$ and $13.2 \%)$. When viewed with ity to manage time $(71.4 \%)$ and knowledge (68.1\%). Not only on a good level, some graduates assess their competencies that are at an excellent level, namely in terms of the use of computers $(30.8 \%)$, ability to solve problems

the competencies required in the performance of the graduates showed an increase. This means that graduates assess their competence to meet the demands of competence in the field of work (Figure 8).

Figure 8

Competency Requirements at Work

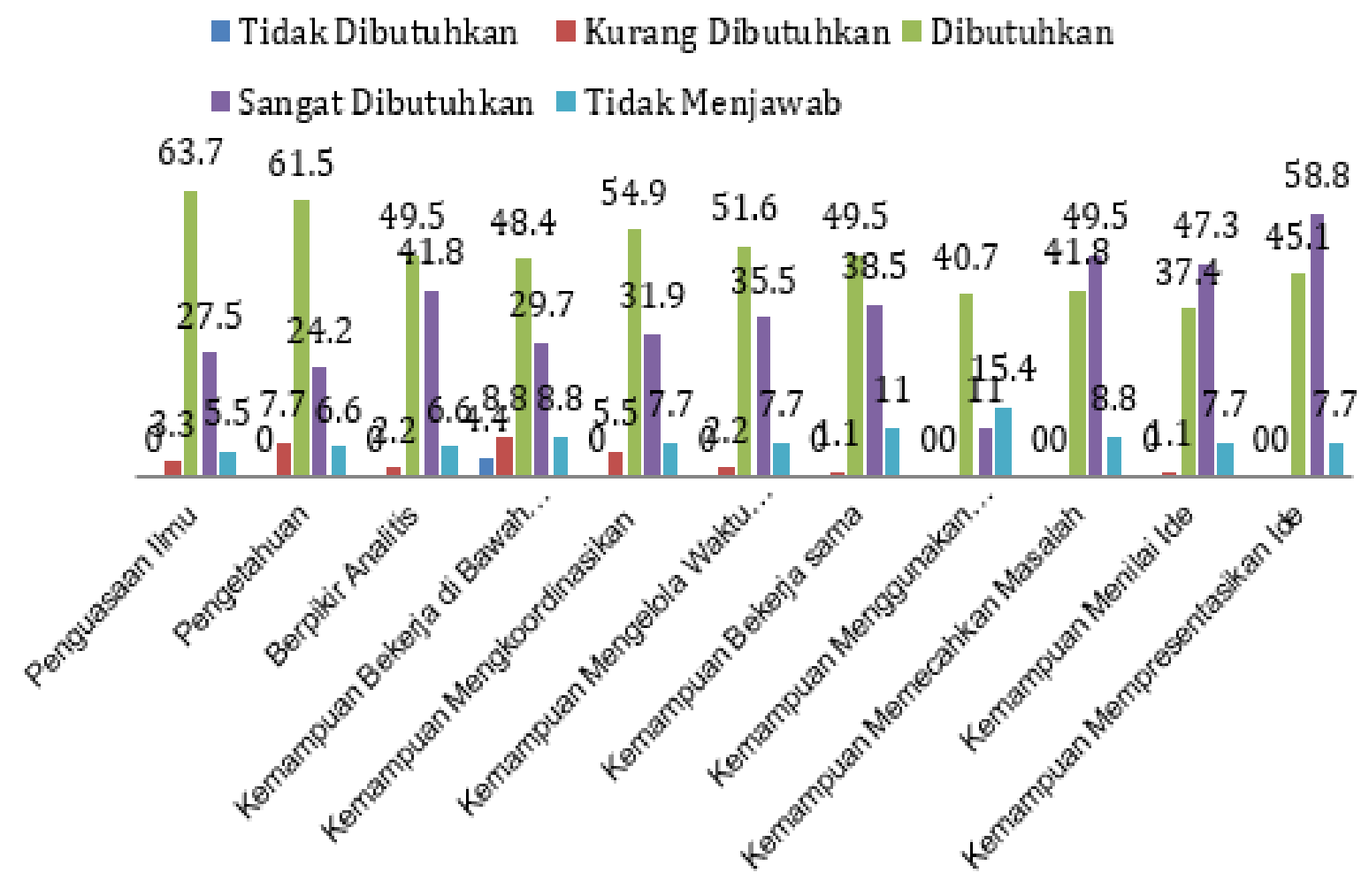

In the picture above shows the opinion work that graduates can meet is the ability to about the competence of the student graduate present ideas (58.8\%), ability to solve problems job requires. From these images in general (49.5\%), the ability to judge the ideas (47.3\%) can be seen that the competence of graduates and the ability to work together $(38.5 \%)$ as to meet the needs in the field of employment. well as the ability to manage time (35.5\%). Competencies that are needed in the field of However, if viewed from the scientific com- 
AGREGAT: Jurnal Ekonomi dan Bisnis

Vol. 3, No. 1, Maret 2019

http://journal.uhamka.ac.id/index.php/agregat

p-ISSN: 2549-5658 e-ISSN: 2549-7243

DOI: 10.22236/agregat_vol3/is1ppc

Hal 95

petence, capability in terms of mastery of sci-

ence and knowledge most respondents assess

their capacity with new can meet the needs of

working at the level of either or needed in the working world.

\section{Conclusions}

The conclusion of this study are that:

Alumni can generally be absorbed in the world of work with the normal waiting period of work which is about 3 months after graduation already got their first job. The majority of alumni working in the field of employment in accordance with their field of study. Alumni considers that the curriculum developed by Febi own good. Almost all the basic core courses organized considered useful in supporting their work. For the method of assessing the Alumni Teaching and Learning Activities to-face classroom activities directly and classroom discussion activities, as well as practice in the field is very important and useful. Alumni consider the hard and soft competencies they have and acquired while studying in Febi has been good. Alumni assess soft skills competencies they have higher than on their hard skills and this is in accordance with the needs of the working world are increasingly demanding mastery of soft skills. However, if compared with the expectation of demands in the workplace still a number of gaps that need to be improved in both the hard skills and soft skills.

It is time for higher education institutions to carry out surveys of alumni search more seri-

ously. The data generated by the survey had an important contribution to the development of higher education institutions. In addition, it is time for higher education institutions adhering to the results of empirical research in the field of higher education decision making process. Very often in education policy changes, for example in terms of the curriculum, without any consideration of empirical data and research results. This of course is ironic because higher education institutions are always seen as a center of scientific activity.

\section{REFERENCE}

Ali Akbar Jono, (2016). KKNI Based Curriculum Implementation Study On English Language Study Program in LPTK Secity of Bengkulu, Manhaj Journal, Vol. 4, No. 1, January-April, 2016.

Directorate General of Higher Education, Curriculum Development Guidelines LPTK, Jakarta, in 2013.

Fitr, Ainil, (2010).Motivation Relationship With Job Waiting Period The duration of the Graduate School of Nursing Usu period of 2008 and 2009, Research Report University of North Sumatra, Medan.

Hasbullah, (1999). Basics of Education, PT. King Grafindo Persada, Jakarta..

State Islamic Institute Raden Intan Bandar Lampung, Profile IAIN Raden Intan Bandar Lampung in 2001.

Jaka, Eka, (2006). Reaching Strategies Work Opportunities Strategy, Elek Media Komputindo, Jakarta..

Indonesian Presidential Regulation No. 8 of 2012 on KKNI, Chapter I, Article 1. 
Schomburg, Handbook for Graduate Tracer Study. Universitatas Kassel, 2003.

Soemantri, Mukminan, Suparmini, and M. Nursa'ban, (2010). Graduate Studies Department of Geography Education Relevance Uny Year 2005 - 2009, UNY, Yogyakarta, 2010.

Suharti, Leili, and FP Laksono, (2012). study Search (Tracer Study) To the Alumni

Program Management Studies Faculty of Economics and Business, University of Satya Discourse, FEB-UKSW Salatiga, 2012.

Suyati, Tri, et al., (2012) Study Search UN Department FIP Against Teachers' Training College Alumni PGRI Semarang, in the Journal of Curriculum Development Framework.
Tirtarahardja, Umar and La Sulo, (2005). Introduction to Education, Revised Edition Cet. II, PT. Rineka Cipta, Jakarta, in 2005.

Wuradji, et al., (2010). Studies Graduate Studies Program Search Education Management Graduate Program, State University of Yogyakarta, Research Reports, Graduate UNY.

Joseph, Muri, (2006). Introduction to Education, Cet. II, PT. Ghalia Indonesia, Jakarta. 